\title{
OSMOTIC, OXIDATIVE AND SALINITY STRESSES UPREGULATE THE EXPRESSIONS OF THIAMINE (vitamin B1) BIOSYNTHESIS GENES (THIC and THI1/THI4) IN OIL PALM (Elaeis guineensis)
}

\section{AISAMUDDIN ARDI ZAINAL ABIDIN*; WONG SOOK YEE*; NUR SYUHADAH ABDUL RAHMAN*; ZAINOR HAFISAH CHE IDRIS* and ZETTY NORHANA BALIA YUSOF*}

\begin{abstract}
Thiamine or vitamin B1 comprises a pyrimidine moiety and a thiazole moiety. Thiamine pyrophosphate (TPP), the active form of thiamine, acts as a cofactor for various major enzymes for example transketolase (TK), $\alpha$-ketoglutarate dehydrogenase (KGDH) and pyruvate dehydrogenase $(P D H)$. In this study, the gene transcripts of first two enzymes in thiamine biosynthesis pathway, THIC and THI1/THI4 were identified and amplified from oil palm tissues. Primers were designed based on sequence comparison of the genes from Arabidopsis thaliana, Zea mays, Oryza sativa and Alnus glutinosa. The oil palm's response in terms of the expression profiles of these two thiamine biosynthesis genes to osmotic stress, salinity stress and oxidative stress were analysed in this project. This is due to the suggestion that TPP plays another important role, which is protecting plants against abiotic and biotic stresses. Both THIC and THI1/THI4 gene transcripts were successfully amplified and the expressions of the gene transcripts were detected using reverse transcriptase polymerase chain reaction (RT-PCR). The levels of expressions were measured and the results showed that the expression of THIC gene transcripts showed increase in gene expression in conjunction with increase concentration of stress inducer.
\end{abstract}

Keywords: thiamine, vitamin B1, osmotic stress, oxidative stress, salinity stress, gene expression.

Date received: 31 March 2016; Sent for revision: 27 May 2016; Received in final form: 9 August 2016; Accepted: 10 August 2016.

\section{INTRODUCTION}

Thiamine is important for all living organism as it serves vital functions in carbohydrate metabolism, nicotinamide adenine dinucleotide phosphate $(\mathrm{NADPH})$ and adenosine triphosphate (ATP) synthesis and also nucleic acids formation (Nosaka, 2006). The active form is known to be thiamine pyrophosphate (TPP) (Pourcel et al., 2013; Tunc-

Department of Biochemistry, Faculty of Biotechnology and Biomolecular Sciences, Universiti Putra Malaysia, 43400 UPM Serdang, Selangor, Malaysia.

E-mail: zettynorhana@upm.edu.my
Ozdemir et al., 2009) and it acts as a cofactor for various key enzymes like pyruvate dehydrogenase (PDH), transketolase (TK) and $\alpha$-ketoglutarate dehydrogenase (KGDH) (Frank et al., 2007). Thiamine production has been shown to increase when stressors are present, be it abiotic or biotic stresses (Tunc-Ozdemir et al., 2009; Balia Yusof et al., 2015).

\section{THIAMINE BIOSYNTHESIS}

Animals and humans must consume thiamine through their diets because they cannot synthesise it themselves while plants and microorganism can 
biosynthesise it de novo (Moulin et al., 2013). The pyrimidine and thiazole moieties are synthesised in distinct branches of the pathway and are then condensed to form thiamine monophosphate (TMP). TMP is then phosphorylated by a specific kinase to form TPP. Plants synthesise TPP de novo from elementary precursors via biosynthetic pathways that are analogous to both bacteria and yeast (Goyer, 2010). The initial phases of TPP biosynthesis include two parallel pathways. One is similar to the mechanism found in bacteria which the pyrimidine branch of thiamine (4-amino-2-methyl5-hydroxymethylpyrimidine monophosphate, HMP-P) is synthesised from 5-aminoimidazole ribonucleotide (AIR) and is catalysed by an enzyme which is encoded by THIC gene and has been identified in Arabidopsis thaliana (Raschke et al., 2007). The other pathway is similar to the mechanism found in yeast (Chatterjee et al., 2008) which the thiazole branch of thiamine [4-methyl5-(2-hydroxyethyl)-thiazole phosphate, HET-P] is synthesised from glycine, nicotinamide adenine dinucleotide $\left(\mathrm{NAD}^{+}\right)$and a sulphur donor protein. THI1 gene, which has been identified in Zea mays and Arabidopsis thaliana (Machado et al., 1996) and its orthologue THI4 which is found in bacteria encodes for the main enzyme that synthesises HET-P. THIC and THI1/THI4 are the genes that encode the first enzymes of pyrimidine and thiazole moieties respectively of the thiamine biosynthesis pathway as shown in Figure 1. These enzymes play a crucial role in thiamine biosynthesis yet they seem to have a non-cofactor function in DNA damage tolerance induced by abiotic and biotic stresses in plants
(Goyer, 2010). Studies on THI4 gene in yeast proved that it has two functions, in thiamine biosynthesis and also in DNA damage tolerance when subjected to abiotic stress (Machado et al., 1997).

\section{Oil Palm's Response towards Abiotic Stresses}

Abiotic stress is triggered by environmental factors which caused a series of changes within the plant at the morphological, physiological, biochemical and molecular level which can then unfavourably affect plant growth, development, and productivity (Apel and Hirt, 2004; Bartels and Sunkar, 2005; Sunkar et al., 2006; Ravet et al., 2009)

Abiotic stresses focused on in this project are osmotic, salinity and oxidative stresses. Osmotic stress occurs when there is an imbalance of water in the cell which may lead to either hypo-osmotic or hyper-osmotic. Climate change may also play a role in inducing osmotic stress towards plants through floods and drought (Murray et al., 2012; Sena et al., 2012). Increase in osmotic potential or osmotic stress by water deficit have shown to reduce photosynthetic abilities and growth in oil palms (Cha-um et al., 2010a). Closely related to osmotic stress is the salinity stress or salt concentration stress. Salinity stress affects plants via two actions which are osmotic stress or ion toxicity. High concentrations of salt in soil decrease the osmotic potential of the soil solution, which make it harder for the root to absorb water from the soil and accumulation of sodium and chloride ions in the cytoplasm of plant can lead to inhibitory of many enzyme reactions (Brinker et al., 2010). Similar

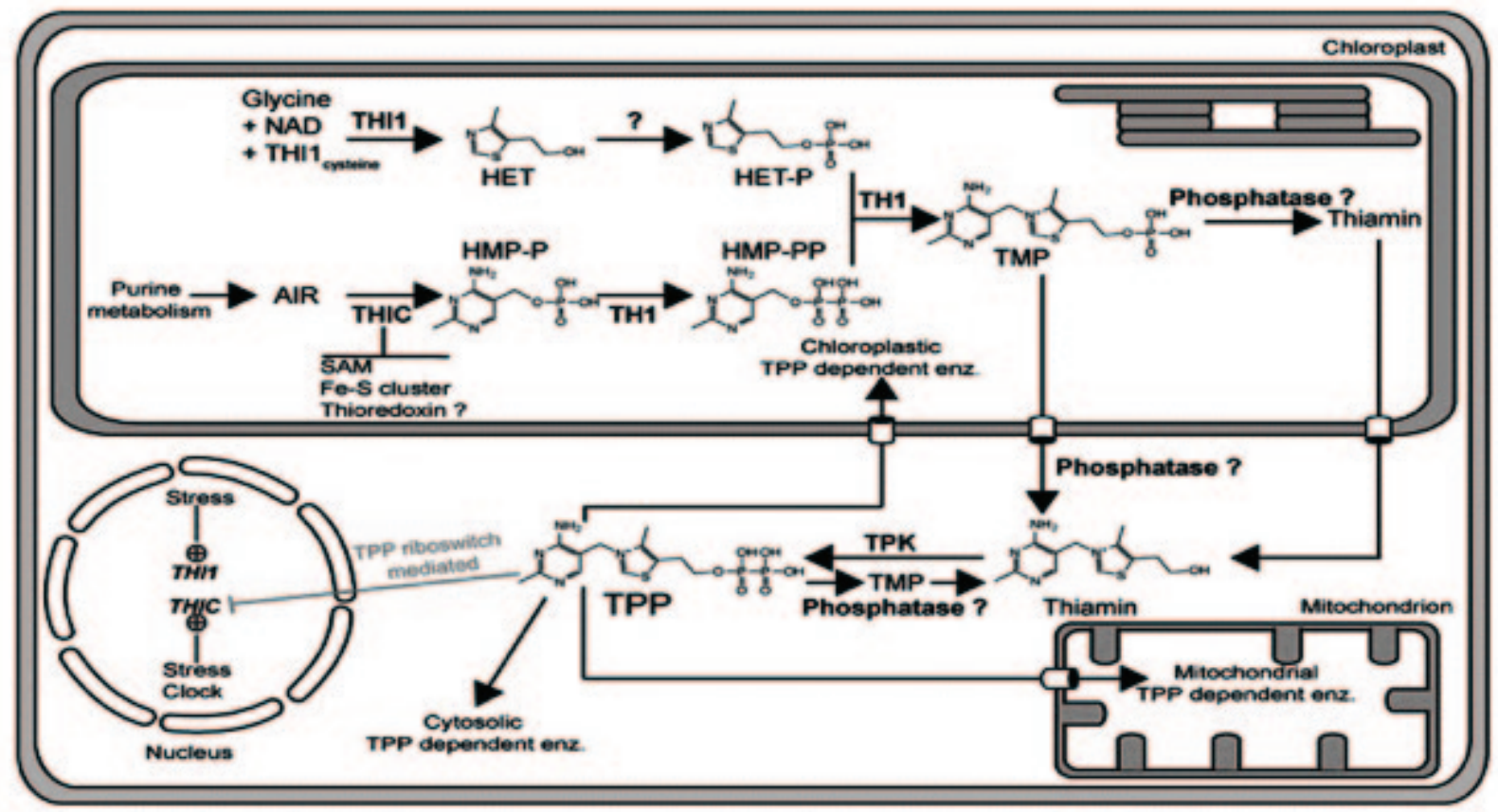

Figure 1. Thiamine biosynthesis pathway of Arabidopsis thaliana. Thiamine monophosphate (TMP) is produced by the condensation of HMPPP and HET-P. To form the active cofactor, thiamine pyrophosphate (TPP), TMP is first dephosphorylated by a phosphatase and then subsequently pyrophosphorylated by TPK (Pourcel et al., 2013). 
pattern of the effect have been shown on oil palms that have been treated with high salt concentration and water deficit as they reduce the photosynthesis potential of the plant and retards the growth (Chaum et al., 2010b). Besides that, the effect of oxidative stress was also tested in this study. Oxidative stress is due to the oxidation effect of reactive oxygen species (ROS) which may be present in the leaf due to stomatal closure or ROS present in the soil. To date, there have not been any particular studies of oxidative stress in oil palm.

\section{Abiotic Stresses and Upregulation of Thiamine Biosynthesis}

Thiamine has been shown to have non-cofactor roles by triggering defence responses in plants (Balia Yusof et al.,2015) and helps in DNA damage tolerance caused by biotic and abiotic stress (Tunc-Ozdemir et al., 2009). There are also other forms of thiamine that do not function as cofactors in the cell like thiamine triphosphate and adenosine thiamine triphosphate that can reach significant levels in Escherichia coli, during amino acid starvation as well as energy stress (Bettendorf and Wins, 2013). Research by RapalaKozik et al. (2008) revealed the regulation of thiamine metabolism in Zea mays seedlings under different abiotic stresses. In the study, Z. mays seedlings were exposed to drought, salinity and oxidative stress. The total thiamine content in the maize seedlings increased under different stress conditions. Experiments by Tunc-Ozdemir et al. (2009) proved that under oxidative stress, high salinity, sugar deprivation and hypoxia, the expression of THI1 gene transcript was increased. Thiamine and TPP serve as essential stress-response molecules during different abiotic stress conditions to combat the condition. Accumulation of thiamine and TPP was observed in Arabidopsis when exposed to abiotic stresses like high light intensity, low temperature, osmotic, salinity and oxidative treatment. Enhanced tolerance towards oxidative stress was observed when plants were supplemented with exogenous thiamine.

Studies by Ahn et al. (2005) and Zhang et al. (1998) also showed that thiamine affects the defence-related genes or systemic acquired response (SAR)-related genes expression in plants for example tobacco, Arabidopsis and wheat. The SAR-related genes were expressed enormously in thiamine treated plants. Recently, a study by Balia Yusof et al. (2015) has proved that there is an upregulation in the expressions of THIC and THI1/ THI4 gene transcripts in Ganoderma boninenseinfected oil palm. Since previous studies have shown that thiamine can improve the immune system of plants, it is believed that sustained accumulation of thiamine can make plants immune to severe diseases.
In this study, the changes in the expressions of thiamine biosynthesis genes (THIC and THI1/ THI4) in oil palm when subjected to polyethylene glycol (PEG)-induced osmotic stress, paraquatinduced oxidative stress and sodium chloride $(\mathrm{NaCl})$-induced salinity stress were analysed. Since thiamine may play an important function in plant protection against stress, it was predicted that there will be an increase in the expressions of THIC and THI1/THI4 gene transcripts once subjected to these various stresses.

\section{MATERIALS AND METHODS}

\section{Plant Materials and Stress Treatment}

A total of 36 six-month old oil palm seedlings $($ Dura $\times$ Pisifera $)$ were purchased from Sime Darby, Banting, Selangor, Malaysia. The seedlings were arranged in a shaded area using randomised complete block design (RCBD) and were subjected to the general nursery practices.

\section{Treatment Application}

Twelve seedlings were used for each treatment. For osmotic stress treatment, three seedlings were used as controls ( $0 \%$ PEG) and similar number of oil palm seedlings with different concentrations of PEG 6000 were given as treatments (1\% PEG, 3\% PEG and $5 \%$ PEG). Similar number of oil palm seedlings was used for oxidative and salinity stress treatment with different concentrations; $0 \mathrm{mM}$ (control), $50 \mathrm{mM}$, $100 \mathrm{mM}$ and $200 \mathrm{mM}$ of $\mathrm{NaCl}$ (salinity treatment) and 0 M, $0.003 \mathrm{M}, 0.006 \mathrm{M}$, and $0.009 \mathrm{M}$ of paraquat concentration (Hextar Paraquat 13) respectively.

\section{Sampling}

Samplings were scheduled at 3-, 7- and 30-day post-treatment. Spear leaves were collected as tissue samples from four seedlings at each sampling. The spear leaves were cleaned and cut before being frozen in liquid nitrogen and kept in $-80^{\circ} \mathrm{C}$ until further use.

\section{Data Mining and Primer Designing}

Data mining includes the gathering of nucleotide sequences of thiamine biosynthesis genes (THIC and THI1/THI4) from different plant species from the GenBank of NCBI database. The nucleotide sequences were aligned using ClustalW program and the consensus regions were identified and used for designing PCR primers.

\section{Total RNA Isolation and Quantification}

Total RNA was isolated using modified RNA extraction protocol by $\mathrm{Li}$ and Trick (2005). The 
tissues used were spear leaves from 3-, 7- and 30day post-treatment. The assessment of RNA quality and integrity was done using a NanoPhotometer (Implen, Germany) and the RNA was kept at $-80^{\circ} \mathrm{C}$.

\section{Amplification of THIC and THI1/THI4 Genes}

RT-PCR was performed using Tetro cDNA Synthesis Kit (Bioline, USA). Complementary DNA (cDNA) was prepared by mixing $5 \mu \mathrm{g} \mu \mathrm{l}^{-1}$ of total RNA, $4 \mu \mathrm{l}$ of $5 \mathrm{X}$ reverse transcriptase buffer, $1 \mu \mathrm{l}$ of $10 \mathrm{mM}$ dNTP mix, $1 \mu \mathrm{l}$ of Oligo (dT)18 Primer, 1 $\mu 1$ of ribosafe RNase inhibitor, $1 \mu \mathrm{l}$ of Tetro reverse transcriptase and up to $20 \mu 1$ of DEPC-treated water. The solution was mixed gently by pipetting and was incubated at $45^{\circ} \mathrm{C}$ for $30 \mathrm{~min}$. The solution was then incubated at $85^{\circ} \mathrm{C}$ for $5 \mathrm{~min}$ to stop the reverse transcriptase reaction and was chilled on ice. The cDNA formed was then used for PCR.

PCR was performed by using MyTaq $^{\mathrm{TM}}$ Red Mix (Bioline, USA). A $25 \mu \mathrm{l}$ reaction was prepared by mixing $1 \mu \mathrm{l}$ of cDNA template, $0.5 \mu \mathrm{l}$ of forward primer, $0.5 \mu \mathrm{l}$ of reverse primer, $12.5 \mu \mathrm{l}$ of MyTaq Red Mix and $10.5 \mu \mathrm{l}$ of deionised water to make up to $25 \mu \mathrm{l}$. The reaction mixture was mixed and placed inside the thermocycler (Biometra, Germany). The PCR cycling requirements included the initial denaturation step which was set at $95^{\circ} \mathrm{C}$ for 2 min for one cycle, followed by 28 repetitive cycles of denaturation step at $95^{\circ} \mathrm{C}$ for $45 \mathrm{~s}$, annealing step at $55^{\circ} \mathrm{C}$ for $45 \mathrm{~s}$ and extension step at $72^{\circ} \mathrm{C}$ for $1 \mathrm{~min}$. The final cycle of extension was set at $72^{\circ} \mathrm{C}$ for $5 \mathrm{~min}$ for one cycle and then held at $4^{\circ} \mathrm{C}$. The PCR product was then kept in the $-20^{\circ} \mathrm{C}$ freezer until further use.

\section{Analysis of PCR Products}

PCR products were analysed using gel electrophoresis and the bands intensities were calculated using ImageJ software (http://imagej. nih.gov/ij/).

\section{DNA Sequencing}

Purified PCR products were sequenced using $1^{\text {st }}$ BASE DNA sequencing service $\left(1^{\text {st }}\right.$ BASE, Singapore). The FASTA sequences were then analysed using Basic Local Alignment Search Tool (BLAST) (https://blast.ncbi.nlm.nih.gov) to find DNA sequences in NCBI database.

\section{RESULTS AND DISCUSSIONS}

\section{Amplification of Gene Transcripts}

Primers were designed based on sequence alignments of different plant species as shown in Table 1. Table 2 shows the primers designed for this study.

The level of gene expressions is shown visually in Figure 2 where both THIC and THI1/THI4 gene transcripts were successfully amplified in nontreated oil palm tissues using the primers designed. The fragment size for THIC primer F2 is $410 \mathrm{bp}$, while the fragment size for THIC primer F3 is $156 \mathrm{bp}$. For THI1/THI4 primer F8, the fragment size is 180 bp. The optimised annealing temperature for THIC primer $\mathrm{F} 3$ and $\mathrm{THI} 1 / \mathrm{THI} 4$ primer $\mathrm{F} 8$ is $55^{\circ} \mathrm{C}$ while for THIC primer $\mathrm{F} 2$ is $48^{\circ} \mathrm{C}$. This finding proved that the gene transcripts of the first two enzymes in the thiamine biosynthesis pathway were successfully amplified from oil palm tissue sample.

\section{Sequencing Analysis}

Purified PCR products were sequenced using $1^{\text {st }}$ BASE DNA sequencing service ( $1^{\text {st }}$ BASE, Singapore) and the FASTA sequences were then analysed using BLAST. For actin gene, the result shows $98 \%$ identity to Elaeis guineensis actin (ACT1) mRNA, complete cds (Accession number: AY550991.1). The $\mathrm{E}$ value is $5 \mathrm{e}-57$. The fragment length amplified

TABLE 1. DATA FROM SELECTED PLANT SPECIES THAT WERE USED FOR PRIMER DESIGNING AND THEIR ACCESSION NUMBER FROM GENBANK OF NCBI DATABASE

\begin{tabular}{lll}
\hline Gene & \multicolumn{1}{c}{ Data from GenBank } & Accession No. \\
\hline THIC & Arabidopsis thaliana phosphomethylpyrimidine synthase mRNA, complete cds & NM_001202705.1 \\
& Arabidopsis thaliana phosphomethylpyrimidine synthase mRNA, complete cds & NM_128517.3 \\
& Arabidopsis thaliana phosphomethylpyrimidine synthase mRNA, complete cds & NM_179804.2 \\
& Zea mays clone 378320 thiamine biosynthesis protein thiC mRNA, complete cds & EU972242.1 \\
& Oryza sativa Japonica Group Os03g0679700 (Os03g0679700) mRNA, complete cds & NM_001057432.1 \\
THI1/THI4 & Arabidopsis thaliana thiazole biosynthetic enzyme mRNA, complete cds & NM_124858.3 \\
& Arabidopsis thaliana Thi1 protein mRNA, complete cds & U17589.1 \\
& Zea mays thiamine biosynthesis1 (thi1), mRNA & No1112226.1 \\
& cds, clone: 12YPR001 & AB110170.1 \\
& A. glutinosa mRNA for thiazole biosynthetic enzyme & X97434.1 \\
\hline
\end{tabular}


TABLE 2. PRIMERS DESIGNED FOR THE AMPLIFICATION OF THIC, THI1/THI4 AND ACTIN GENE TRANSCRIPTS

\begin{tabular}{|c|c|c|}
\hline Description & Primer's name & Sequences \\
\hline \multirow[t]{11}{*}{ Primers designed for THIC gene } & THIC F1 & 5' - CATTCСТCTTACAGCAAAG -3' \\
\hline & THIC R1 & 5'- GTGATGTGATCATAACCAGG -3' \\
\hline & THIC F2 & 5' - CTTACAGCAAAGAGAATGAC -3' \\
\hline & THIC R2 & 5'- GTGATGTGATCATAACCAGG -3' \\
\hline & THIC F3 & 5'- CTTACAGCAAAGAGAATGAC -3' \\
\hline & THIC R3 & 5' - GTGATGTGATCATAACCAGG -3' \\
\hline & THIC F4 & 5'- GGGATCATAACTGAGGCGGG -3' \\
\hline & THIC R4 & 5' - ATCAGCTCCCCACATGGTTG -3' \\
\hline & THIC F5 & 5' - CATAACTGAGGCGGGCGATT -3' \\
\hline & THI4 R5 & 5'- ACATGGTTGCCCAACTTCCT -3' \\
\hline & THI4 F6 & 5' - СТСТСТТСАССТСААССАТС -3’ \\
\hline \multirow[t]{5}{*}{ Primers designed for THI1/THI4 gene } & THI4 R6 & 5'- CATGACGGACATGATCAC -3' \\
\hline & THI4 F7 & 5'- GCGTTGAACAGCTTCACG -3' \\
\hline & THI4 R7 & 5' - СТСТСТТСАССТСААССАТС -3' \\
\hline & THI4 F8 & 5' - GCCAATACTCTTCAGCCTC -3' \\
\hline & THI4 R8 & 5' - CCAGCTTTTGGCTCGTCCTA -3' \\
\hline \multirow[t]{2}{*}{ Primer for Actin gene } & ACT1AS1 & 5' - CTTGCTCCAAGCAGCATGA -3' \\
\hline & ACT1S1 & 5'- AGAAGCACTTCCGGTGCACG -3' \\
\hline
\end{tabular}

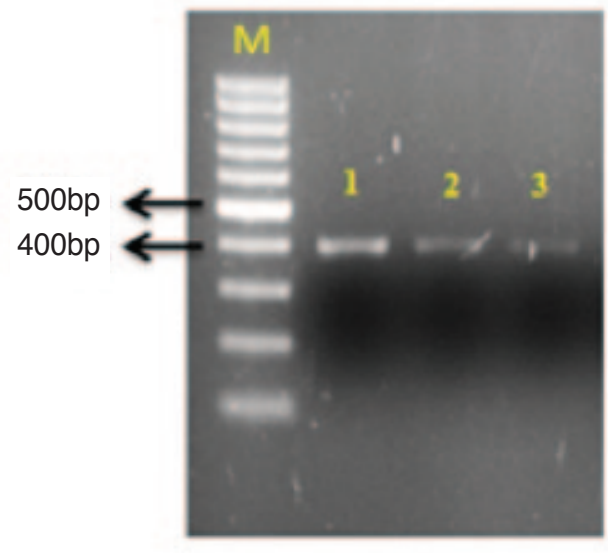

(a)

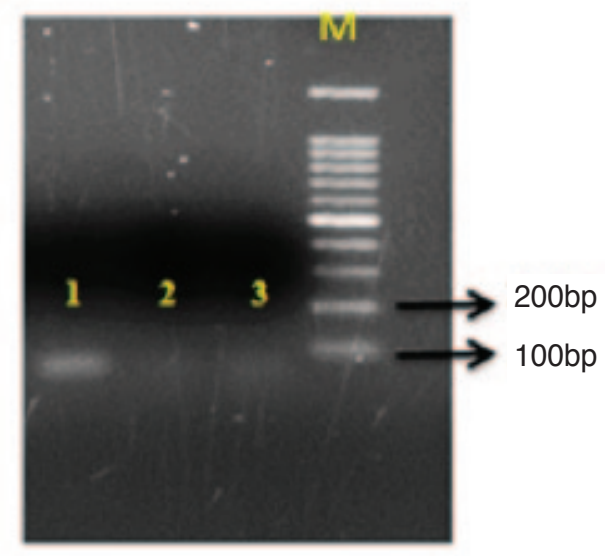

(c)

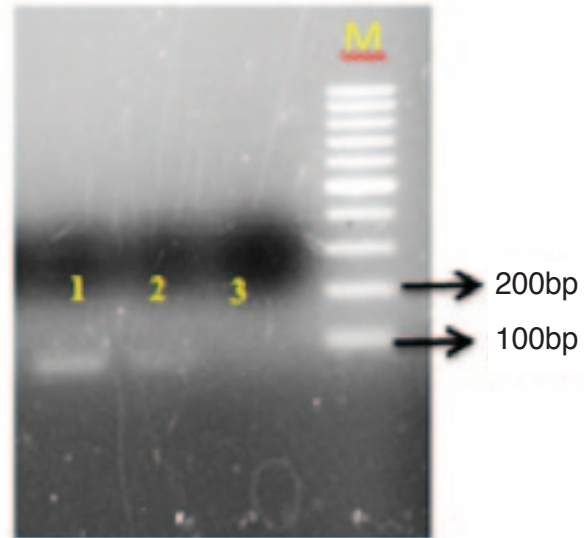

(b)

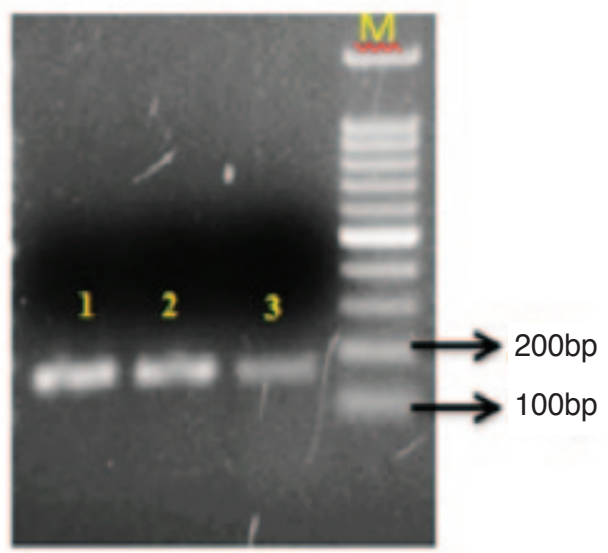

(d)

Figure 2. Amplification of (a) THIC gene using primer F2; (b) THIC gene using primer F3; (c) THI1/THI4 gene using primer F8; (d) actin gene from non-treated oil palm tissues. Lane M - double stranded DNA molecular weight markers (HyperLadder ${ }^{\mathrm{TM}} 100 \mathrm{bp}$ DNA Ladder, Bioline). Lane 1 - spear leaf three days; lane 2 - spear leaf seven days; lane 3 - spear leaf 30 days post-treatment. 
by the primer is $135 \mathrm{bp}$. For THIC primer F2 gene, the result shows $99 \%$ identity to Elaeis guineensis phosphomethylpyrimidine synthase, chloroplastic (LOC105046270), transcript variant X10, mRNA (Accession number: XM_010924818.1). The E value is 0.0 . The fragment length amplified by the primer is $371 \mathrm{bp}$. For THIC primer F3 gene, the result shows $92 \%$ identity to Elaeis guineensis phosphomethylpyrimidine synthase, chloroplastic (LOC105046270), transcript variant X10, mRNA (Accession number: XM_010924818.1). The $E$ value is $1^{\mathrm{e}-72}$. The fragment length amplified by the primer is $201 \mathrm{bp}$. However, for THI1/ THI4 primer F8 gene, no significant similarity was found.

\section{Effect on Thiamine Biosynthesis Genes in Oil Palm under Osmotic Stress}

The difference in the level of expressions could be seen where there was an increased expression in the PEG-treated tissue samples for both gene transcripts as shown in Figure 3. The amplified gene transcripts were run alongside actin gene as control.

Figure 4 shows that a fast sensing response (on Day 3) by oil palm seedlings to osmotic stress could be seen through the highest expression of THIC gene (200\% increase compared to the control) in the application of $1 \%$ PEG. In the presence of $1 \%$ PEG, on Day 7, an increased expression of up to $65 \%$ could be seen for THIC gene transcript as compared to the untreated plant. The level of expressions of THI1/THI4 gene transcripts in the presence of $1 \%$ PEG showed similar result as THIC gene, where the highest expression is on Day 3 post-treatment (100\% increase compared to the control) followed by an increment of $57 \%$ on Day 7 post-treatment and $28 \%$ increase on Day 30 post-treatment. THIC and THI1/THI4 gene expressions were also altered in the presence of $3 \%$ PEG with a day profile similar to that of $1 \%$ PEG stress condition but increases only up to 1.7 -fold. The gene expression pattern in the presence of 5\% PEG is in fact different compared to the other concentrations of PEG. The highest gene expressions for both THIC and THI1/THI4 gene transcripts are on Day 7 post-treatment (1.2-fold).

It is believed that stress-triggered damage affects the important pathways and therefore an apparent need to upregulate the thiamine biosynthetic process is necessary. This test evaluated the genes encoding for the biosynthesis of the pyrimidine and thiazole moieties of thiamine (THIC and THI1/THI4). The hypothesis for this study is that the level of expressions for THIC and THI1 / THI4 gene transcripts will increase in PEG-treated oil palm tissue samples. However, the decrease of the expressions of THIC and THI1/THI4 gene
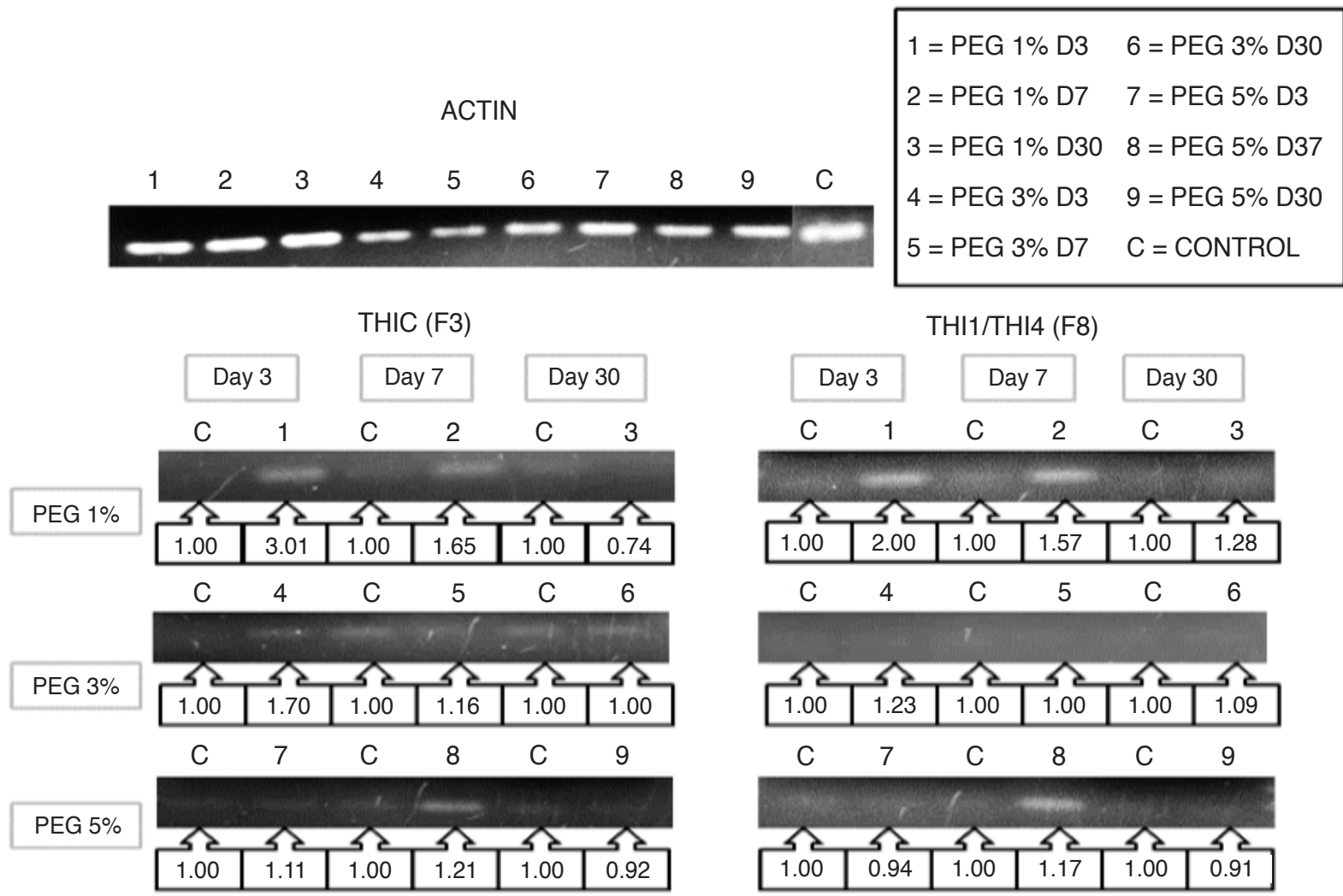

Figure 3. The levels of gene expressions for THIC and THI1/THI4 in treated and non-treated oil palm spear leaf tissue samples analysed using Image software. Lane C represents non-treated oil palm spear leaf tissue sample while lanes 1-9 represent treated oil palm spear leaf tissue samples. 
THIC (F3)

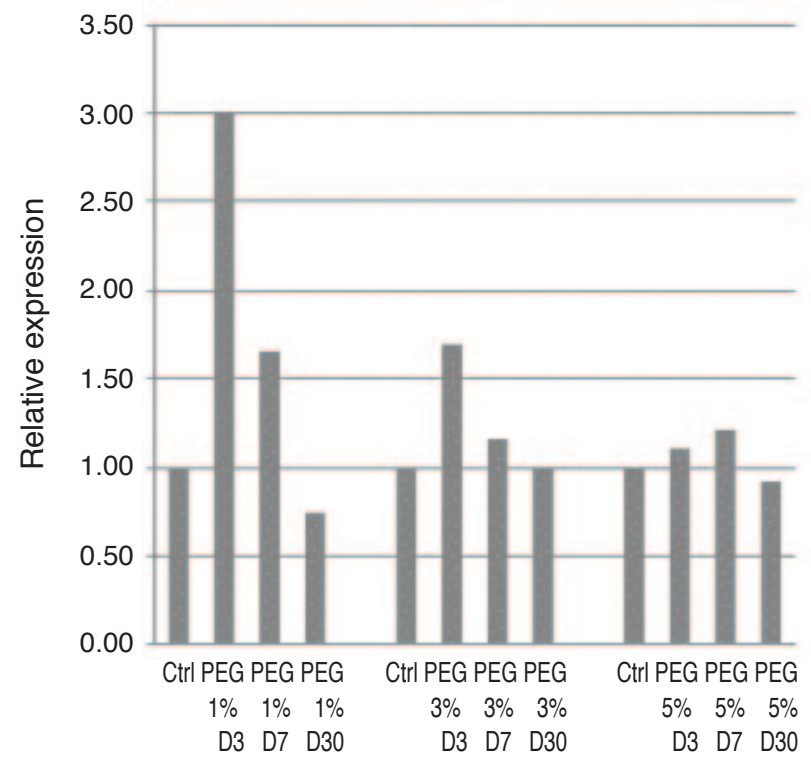

THI1/THI4 (F8)

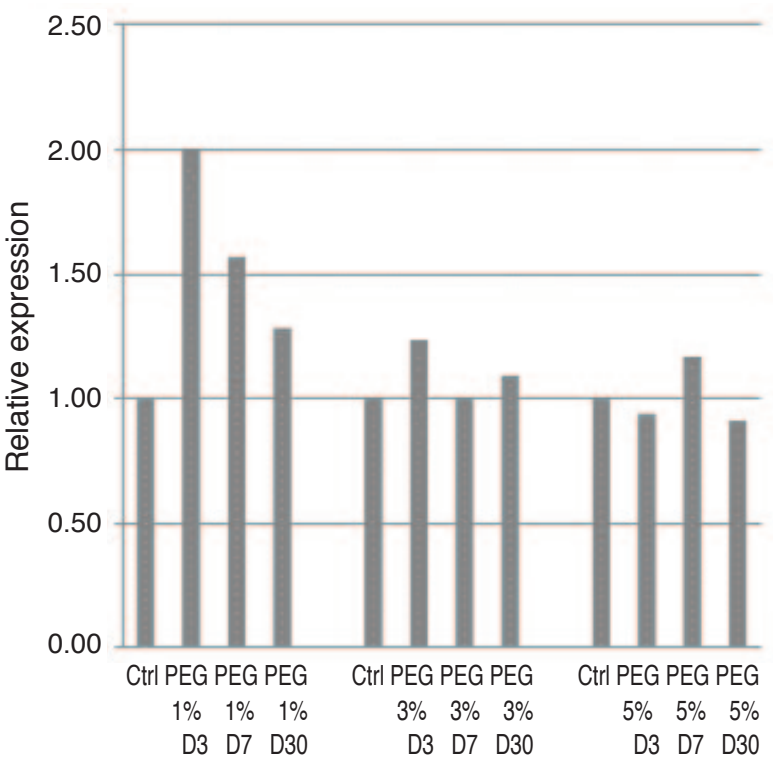

Figure 4. Day-dependent response of oil palm seedlings to osmotic stress revealed through THIC and THI1/THI4 gene expression changes.

transcripts along the period of stress treatment could be due to the fact that the palms are starting to adapt to the stress conditions. This may show a hormonal signalling mechanism rather than water availability that controls plant growth under these conditions (Munns et al., 2000). In this study, the observed changes for THIC gene transcript expression were higher compared to THI1/THI4. Studies on THI4 gene in yeast have proved that it has a dual role, in thiamine biosynthesis and also in DNA damage tolerance when subjected to abiotic stress (Machado et al., 1997). As a whole, the results showed that indeed, both gene transcripts expression levels were elevated in PEG-treated tissue samples. In relation to this result, a study done by Al-Khayri and AlBahrany (2004) has showed that increase of PEG concentrations exposure to oil palm have led to an increase accumulation of proline. The increase of proline may indirectly lead to the synthesis of THI4 as the enzyme structure contains proline in a cis formation forming a loop region where isomerisation of proline may lead to product released (Jurgenson et al., 2009).

\section{Effect on Thiamine Biosynthesis Genes in Oil Palm under Salinity Stress}

In this project, we hypothesised that in response to salt stress, the expression levels of THIC and THI1/THI4 will increase and can lead to the accumulation of thiamine. The expression of these two main genes involved in thiamine biosynthesis pathway in oil palm was observed according to different days (Day 3, Day 7 and Day 30) with different concentrations (50 mM, $100 \mathrm{mM}$ and 200
$\mathrm{mM} \mathrm{NaCl}$ ) of $\mathrm{NaCl}$. Table 3 shows the appearance of single band of THIC gene transcript and its level of expression. Theoretically, expression level of THIC and THI1/THI4 in treated spear leaf tissue sample at Day 3 was expected to be higher than Day 7 and Day 30. This is due to the thiamine immediate response in protecting the plant cells against stress especially salt stress. Under the influence of $\mathrm{NaCl}$, at the concentration of $50 \mathrm{mM}$, plants encountered mild salt stress while at $200 \mathrm{mM}$, plants faced maximum saline condition.

For THIC gene transcript for this particular stress induction, treatment of oil palm seedlings with $50 \mathrm{mM} \mathrm{NaCl}$ after seven days showed a level of expression of $331 \%$ while just $165 \%$ on Day 3 and just $33 \%$ on Day 30. The low expression level on Day 30 was hypothesised to be due to the adaptation of the plants towards the applied stress. When treated with $100 \mathrm{mM} \mathrm{NaCl}$, mixed results were obtained where THIC tends to be expressed quite highly at $186 \%$ on Day 3 while just $26 \%$ on Day 7 (Table 3). On Day 30 however, expression level was recorded at $191 \%$ almost similar to the amount expressed initially on Day 3. The $200 \mathrm{mM} \mathrm{NaCl}$ treated tissue samples followed similar pattern of THIC expression level as the ones treated with 50 $\mathrm{mM} \mathrm{NaCl}$ where the expression was seen highest at Day 7 post-treatment. Table 4 shows the single band of THI1 / THI4 gene transcript and its level of expression.

On the other hand, THI1/THI4 showed no expression on Day 3 post-treatment with $50 \mathrm{mM}$ $\mathrm{NaCl}$ but increased significantly on Day 7 with $200 \%$ of level of expression and $511 \%$ on Day 30 post-treatment. For the plants treated with 100 
TABLE 3. THE AMPLIFICATION OF THIC GENE TRANSCRIPT AND ITS LEVEL OF EXPRESSION OF SALINE TREATED AND NON-TREATED OIL PALM SEEDLINGS AT DAY 3, 7 AND 30 POST-TREATMENT

\begin{tabular}{|c|c|c|c|c|c|c|}
\hline $\begin{array}{l}\text { Primer/ } \\
\text { sampling } \\
\text { day }\end{array}$ & \multicolumn{2}{|c|}{ Day 3} & \multicolumn{2}{|c|}{ Day 7} & \multicolumn{2}{|c|}{ Day 30} \\
\hline \multirow[t]{7}{*}{ THIC (F3) } & & 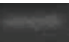 & \multicolumn{2}{|c|}{$x^{2}=$} & $=$ & \\
\hline & Control & $\begin{array}{l}\mathrm{NaCl} \\
50 \\
\mathrm{mM}\end{array}$ & Control & $\begin{array}{l}\mathrm{NaCl} \\
50 \\
\mathrm{mM}\end{array}$ & Control & $\begin{array}{l}\mathrm{NaCl} \\
50 \\
\mathrm{mM}\end{array}$ \\
\hline & 1.00 & 2.65 & 1.00 & 4.31 & 1.00 & 1.33 \\
\hline & Control & $\begin{array}{l}\mathrm{NaCl} \\
100 \\
\mathrm{mM}\end{array}$ & Control & $\begin{array}{l}\mathrm{NaCl} \\
100 \\
\mathrm{mM}\end{array}$ & Control & $\begin{array}{l}\mathrm{NaCl} \\
100 \\
\mathrm{mM}\end{array}$ \\
\hline & 1.00 & 2.86 & 1.00 & 0.74 & 1.00 & 2.91 \\
\hline & Control & $\begin{array}{l}\mathrm{NaCl} \\
200 \\
\mathrm{mM}\end{array}$ & Control & $\begin{array}{l}\mathrm{NaCl} \\
200 \\
\mathrm{mM}\end{array}$ & Control & $\begin{array}{l}\mathrm{NaCl} \\
200 \\
\mathrm{mM}\end{array}$ \\
\hline & 1.00 & 1.23 & 1.00 & 1.64 & 1.00 & 1.05 \\
\hline
\end{tabular}

$\mathrm{mM} \mathrm{NaCl}$, the expression level of THI1/THI4 was highest on Day 3 with 357\% followed by Day 30 with $261 \%$. However, Day 7 showed no expression with just $83 \%$ compared to the control. This fluctuating pattern may be due to external disturbances such as the weather and temperature. For oil palm treated with $200 \mathrm{mM} \mathrm{NaCl}$, the highest expression level for this gene was observed on Day 3 with $723 \%$, followed by Day 7 with level of expression 102\% and Day 30 with just $61 \%$ compared to control sample of $100 \%$.

These results show that there was a difference in level of increment for both THIC and THI1/THI4 genes. Overall, THI1/THI4 gene showed higher increment in the level of expression compared to THIC gene transcript. This is due to the fact that THI1/THI4 has varied functions. As previously mentioned, it does not only catalyse the conversion of $\mathrm{NAD}^{+}$and glycine to an adenylated thiazole intermediate in thiamine biosynthesis pathway, but it also has roles in DNA damage tolerance when subjected to stress (Machado et al., 1997). In another study by (Cha-um et al., 2010b), under the same treatment at $200 \mathrm{mM}$ of $\mathrm{NaCl}$, oil palm has showed an increase in proline content up to $2.8 \mu \mathrm{mol} \mathrm{g}^{-1}$ in 14 days from $0.7 \mu \mathrm{mol} \mathrm{g}^{-1}$ in Day 0 . This result shows a similar pattern with the results in oil palm under osmotic stress which could show that there
TABLE 4. THE AMPLIFICATION OF THI1/THI4 GENE TRANSCRIPT AND ITS LEVEL OF EXPRESSION OF SALINE TREATED AND NON-TREATED OIL PALM SEEDLINGS AT DAY 3, 7 AND 30 POST-TREATMENT

\begin{tabular}{|c|c|c|}
\hline $\begin{array}{l}\text { Primer/ } \\
\text { sampling } \\
\text { day }\end{array}$ & Day 3 & Day 7 \\
\hline
\end{tabular}

\begin{tabular}{|c|c|c|c|c|c|c|}
\hline THII / THI4 & & & & $=$ & & $4=$ \\
\hline & Control & $\begin{array}{l}\mathrm{NaCl} \\
50 \\
\mathrm{mM}\end{array}$ & Control & $\begin{array}{l}\mathrm{NaCl} \\
50 \\
\mathrm{mM}\end{array}$ & Control & $\begin{array}{l}\mathrm{NaCl} \\
50 \\
\mathrm{mM}\end{array}$ \\
\hline & 1.00 & 0.89 & 1.00 & 3.00 & 1.00 & 6.11 \\
\hline & Control & $\begin{array}{l}100 \\
\mathrm{mM}\end{array}$ & Control & $\begin{array}{l}100 \\
\mathrm{mM}\end{array}$ & Control & $\begin{array}{l}100 \\
\mathrm{mM}\end{array}$ \\
\hline & 1.00 & 4.57 & 1.00 & 0.17 & 1.00 & 3.61 \\
\hline & Control & $\begin{array}{l}\mathrm{NaCl} \\
200 \\
\mathrm{mM}\end{array}$ & Control & $\begin{array}{l}\mathrm{NaCl} \\
200 \\
\mathrm{mM}\end{array}$ & Control & $\begin{array}{l}\mathrm{NaCl} \\
200 \\
\mathrm{mM}\end{array}$ \\
\hline & 1.00 & 8.23 & 1.00 & 2.02 & 1.00 & 0.39 \\
\hline
\end{tabular}

is a relation between proline and thiamine and its correlations.

\section{Effect on Thiamine Biosynthesis Genes in Oil Palm under Oxidative Stress}

The difference in the level of expressions could be seen where there was an increase in the paraquattreated tissue samples for both gene transcripts as shown in Table 5. The gene transcripts were run alongside the actin gene as control. Based on Table 5, the non-treated seedlings act as a control which is presented as value one. For paraquattreated seedlings, the intensity of the amplified gene transcripts increased which suggests the upregulation of the thiamine genes expressions level both in THIC and THI1/THI4. The concentrations of the paraquat $(\mathrm{PQ})$ used were $0.003 \mathrm{M}, 0.006 \mathrm{M}$, and $0.009 \mathrm{M}$. At all the concentrations given, there were an upregulation of THIC and THI1/THI4 genes transcripts observed especially on Day 3. For THIC gene transcript, the highest upregulation was observed for PQ $0.009 \mathrm{M}$, three days posttreatment. However, the expression was observed to be decreasing for PQ $0.003 \mathrm{M}$, seven days posttreatment. In general, for any given concentration, the expression levels were shown to be increasing up to a point and started to decrease over time. 
TABLE 5. THE COMPARISON OF INTENSITIES BETWEEN (A) CONTROL SPEAR LEAF WITH (B) PARAQUAT-TREATED SPEAR LEAF OF OIL PALM. THE EXPRESSION LEVEL OR THE INTENSITY OF THE BAND, THIC AND THI1/THI4 GENE TRANSCRIPTS WERE MEASURED BY IMAGEJ SOFTWARE

\begin{tabular}{|c|c|c|c|c|c|c|c|}
\hline \multirow{2}{*}{$\frac{\text { Gene }}{\text { THIC Gene }}$} & \multirow{2}{*}{$\begin{array}{l}\text { Treatments } \\
0.003 \mathrm{M}\end{array}$} & \multicolumn{2}{|c|}{ Day 3} & \multicolumn{2}{|c|}{ Day 7} & \multicolumn{2}{|c|}{ Day 30} \\
\hline & & (a) & (b) & (a) & (b) & (a) & (b) \\
\hline & & & 2.962 & 1 & 1.284 & 1 & 0.288 \\
\hline & $0.006 \mathrm{M}$ & (a) & (b) & (a) & (b) & (a) & (b) \\
\hline & & & 2.812 & 1 & 1.615 & 1 & 1.705 \\
\hline & $0.009 \mathrm{M}$ & (a) & (b) & (a) & (b) & (a) & (b) \\
\hline & & & 3.074 & 1 & 1.166 & 1 & 1.338 \\
\hline \multirow[t]{6}{*}{ THIC/THI4 } & $0.003 \mathrm{M}$ & (a) & (b) & (a) & (b) & (a) & (b) \\
\hline & & 1 & 1.340 & 1 & 1.676 & 1 & 1.261 \\
\hline & $0.006 \mathrm{M}$ & (a) & (b) & (a) & (b) & (a) & (b) \\
\hline & & 1 & 2.358 & 1 & 2.631 & 1 & 2.268 \\
\hline & $0.009 \mathrm{M}$ & (a) & (b) & (a) & (b) & (a) & (b) \\
\hline & & 1 & 0.971 & 1 & 2.389 & 1 & 0.948 \\
\hline
\end{tabular}

For 30 days post-treatment, most of the samples showed no expression of the THIC gene transcript. This might be due to the fact that the seedlings had adapted to the condition applied or the plant is exercising another mechanism to cause such change. For THI1/ THI4 gene transcript, it was observed that the highest expression was detected for PQ 0.006 M, seven days post-treatment. The same pattern was observed for PQ $0.009 \mathrm{M}$.

For 30 days post-treatment, upregulation of gene transcript was not observed for PQ 0.009. In contrast, some upregulation could be observed for PQ 0.003 M and PQ 0.006 M (Table 5). As we can see in Figure 5, paraquat treatment affected the expression of THI1 / THI4 gene (Figure $5 b$ ) generally in a similar pattern where it is upregulated as the concentration of paraquat given increases and declines over the time course. However, THIC gene (Figure 5a) was highly upregulated at the initial exposure to the treatment. This may due to the fact that THI1/ THI4 enzyme does have another function other than being involved in thiamine biosynthesis, such as playing a role in DNA damage repair. The expression of THI1/THI4 gene transcript on three days post-treatment is lower than seven days posttreatment may be due to THI1/THI4 is involved in another role in plant at that point of time. This study shows a similar result with thiamine biosynthesis response in Arabidopsis thaliana as there is an upregulation of THI1 and THIC gene expression in response to oxidative stress (Rapalakozik et al., 2012). 


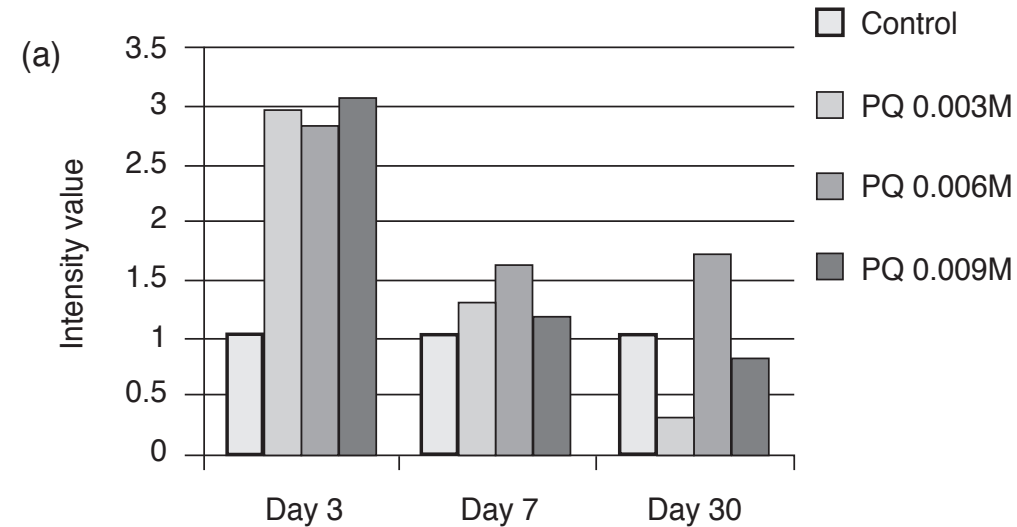

Day of the treatment

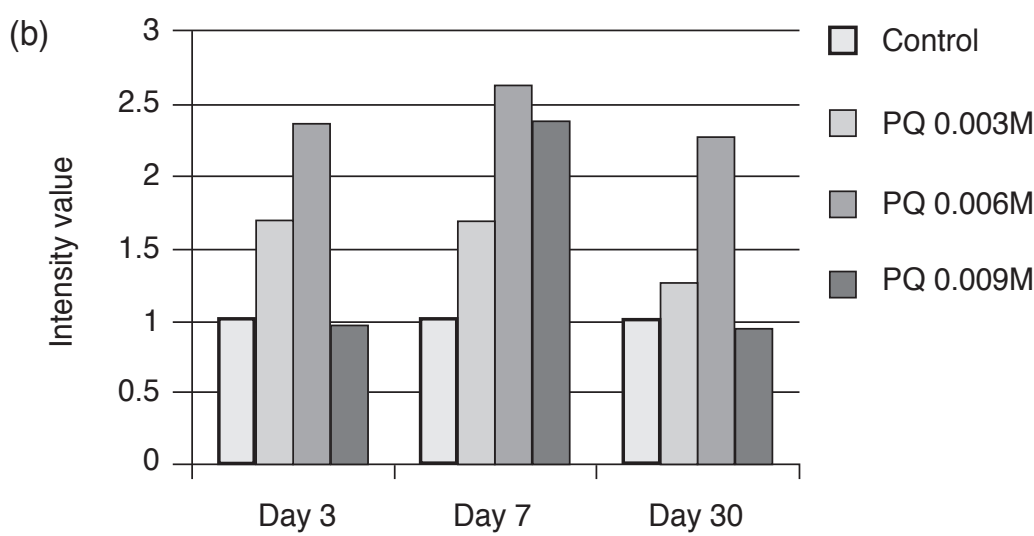

Day of the treatment

(c)

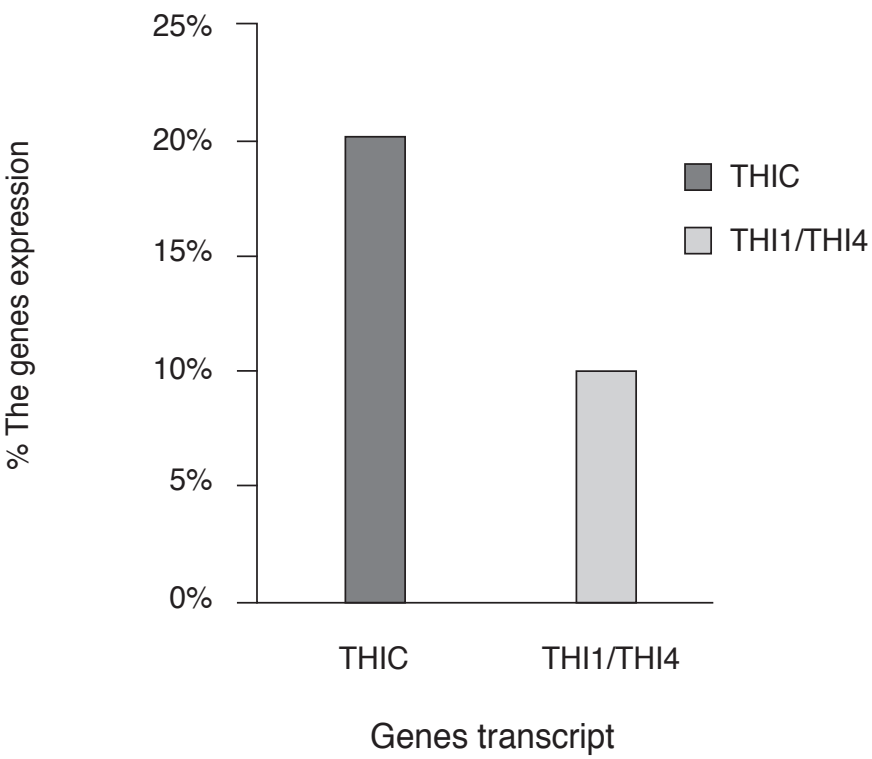

Figure 5. Analysis of the intensity of gene transcripts using ImageJ software. (a) THIC gene transcript, (b) THI1/THI4 gene transcript, and (c) the comparison of expressions of THIC and THI1/THI4 gene transcripts with control sample. 


\section{CONCLUSION}

Overall, in response to the three abiotic stresses, oil palm showed an increase in the gene expression of the first two enzymes in the thiamine biosynthesis pathway. These observations may prove that the translated proteins are vulnerable to damage under unfavourable conditions. An increase of transcription is therefore needed to maintain the proper thiamine cellular levels as it is crucial to develop new adaptation strategies and to overcome the impacts of stress. These suggest that thiamine biosynthesis in plants are tightly modulated during stress sensing and adaptation.

For future work, total thiamine content determination needs to be carried out to confirm that the upregulation of the expression of thiamine biosynthesis genes will result in thiamine accumulation overall. Besides that, studies on the other genes encoding for other enzymes in the thiamine biosynthesis pathway in oil palm will be useful in order to elucidate the regulation of thiamine biosynthesis in oil palm. It is believed that overexpression of thiamine or the specific enzymes in thiamine biosynthesis pathway will contribute to a more stress-tolerant oil palm variety.

\section{ACKNOWLEDGEMENT}

This work was carried out with the support of Putra Grant Universiti Putra Malaysia (Project No. 9425900), Universiti Putra Malaysia, Serdang, Selangor, Malaysia.

\section{REFERENCES}

AL-KHAYRI, J M and AL-BAHRANY, A M (2004). Growth, water content, and proline accumulation in drought-stressed callus of date palm. Biol Plant, 48: 105-108.

AHN, I P; KIM, S and LEE, Y H (2005). Vitamin B1 functions as an activator of plant disease resistance. Plant Physiology, 138: 1505-1515.

APEL, K and HIRT, H (2004). Reactive oxygen species: metabolism, oxidative stress, and signal transduction. Annual Review of Plant Biology, 55: 373399.

BALIA YUSOF, Z N; BORHAN, F P; MOHAMAD, F A and RUSLI, M H (2015). The effect of Ganoderma boninense infection on the expressions of thiamine (vitamin B1) biosynthesis genes in oil palm. J. Oil Palm Res. Vol. 27: 12-18.

BARTELS, D and SUNKAR, R (2005). Drought and salt tolerance in plants. Critical Reviews in Plant Science, 21: 1-36.
BETTENDORFF, L and WINS, P (2013). Thiamine triphosphatase and the CYTH superfamily of proteins. FEBS J., 280(24): 6443-6455.

BRINKER, M; BROSCHÉ, M; VINOCUR, B; ABOOGIALA, A; FAYYAZ, P; JANZ, D and ALTMAN, A (2010). Linking the salt transcriptome with physiological responses of a salt-resistant Populus species as a strategy to identify genes important for stress acclimation. Plant Physiology, 154(1): 16971709.

CHA-UM, S; TAKABE, $\mathrm{T}$ and KIRDMANEE, C (2010a). Osmotic potential, photosynthetic abilities and growth characters of oil palm (Elaeis guineensis Jacq.) seedlings in responses to polyethylene glycolinduced water deficit. African J. Biotechnology, 9: 6509-6516.

CHA-UM, S; TAKABE, T and KIRDMANEE, C (2010b). Ion contents, relative electrolyte leakage, proline accumulation, photosynthetic abilities and growth characters of oil palm seedlings in response to salt stress. Pak. J. Bot., 42: 2191-2020.

CHATTERJEE, A; SCHROEDER, F C; JURGENSON, C T; EALICK, S E and BEGLEY, T P (2008). Biosynthesis of the thiamin-thiazole in eukaryotes: Identification of a thiazole tautomer intermediate. J. Amer. Oil Chem. Soc., 130: 11394-11398.

FRANK, R A W; LEEPER, F J and LUISI, B F (2007). Structure, mechanism and catalytic duality of thiamine-dependent enzymes. Cellular and Molecular Life Sciences, 64: 892-905.

GOYER, A (2010). Thiamine in plants: aspects of its metabolism and functions. Phytochemistry, 71: 16151624.

JURGENSON, C T; BEGLEY, T P; and EALICK, S E (2009). The structural and biochemical foundations of thiamin biosynthesis. Annual Review of biochemistry, 78: 569-603.

LI, Z and TRICK, H N (2005). Rapid method for high-quality RNA isolation from seed endosperm containing high levels of starch. BioTechniques, 38: $872-876$

MACHADO, C R; DE OLIVEIRA, R L C; BOITEUX, S; PRAEKELT, U M; MEACOCK, P A and MENCK, C F M (1996). Thi1, a thiamine biosynthetic gene in Arabidopsis thaliana, complements bacterial defects in DNA repair. Plant Molecular Biology, 31: 585-593.

MACHADO, C R; PRAEKELT, U M; DE OLIVEIRA, R C; BARBOSA, A C C; BYRNE, K L; MEACOCK, P A and MENCK, C F M (1997). Dual role for the 
yeast THI4 gene in thiamine biosynthesis and DNA damage tolerance. J. Molecular Biology, 273: 114-121.

MOULIN, M; NGUYEN, G T D T; SCAIFE, M A; SMITH, A G and FITZPATRICK, T B (2013). Analysis of Chlamydomonas thiamin metabolism in vivo reveals riboswitch plasticity. Proc. of the National Academy of Sciences USA, 110: 14622-14627.

MUNNS, R; PASSIOURA, J B; GUO, J; CHAZEN, O and CRAMER, G R (2000). Water relations and leaf expansion: importance of time scale. J. Experimental Botany, 51: 1495-1504.

MURRAY, S J; FOSTER, P N and PRENTICE, I C (2012). Future global water resources with respect to climate change and water withdrawals as estimated by a dynamic global vegetation model. J. Hydrology, 448: $14-29$.

NOSAKA, K (2006). Recent progress in understanding thiamin biosynthesis and its genetic regulation in Saccharomyces cerevisiae. Applied Microbiology and Biotechnology, 72: 30-40.

POURCEL, L; MOULIN, $\mathrm{M}$ and FITZPATRICK, T B (2013). Examining strategies to facilitate vitamin B1 biofortification of plants by genetic engineering. Frontiers in Plant Science, 4: 1-8.

RAPALA-KOZIK, M; KOWALSKA, E and OSTROWSKA, K (2008). Modulation of thiamine metabolism in Zea mays seedlings under conditions of abiotic stress. J. Experimental Botany, 59: 4133-4143.

RAPALA-KOZIK, M; WOLAK, N; KUJDA, M and BANAS, A K (2012). The upregulation of thiamine (vitamin B 1) biosynthesis in Arabidopsis thaliana seedlings under salt and osmotic stress conditions is mediated by abscisic acid at the early stages of this stress response. BMC Plant Biology, 12: 1.
RASCHKE, M; BÜRKLE, L; MÜLLER, N; NUNES-NESIA, FERNIE, A R; ARIGONI, D and FITZPATRICK, T B (2007). Vitamin B1 biosynthesis in plants requires the essential iron-sulfur cluster protein, ThiC. Proc. of the National Academy of Sciences USA, 104: 19637-19642.

RAVET, K; TOURAINE, B; BOUCHEREZ, J; BRIAT, J F; GAYMARD, F and CELLIER, F (2009). Ferritins control interaction between iron homeostasis and oxidative stress in Arabidopsis. Plant J., 57: 400-412.

SENA, J A; DE DEUS, L A B; FREITAS, M A V and COSTA, L (2012). Extreme events of droughts and floods in Amazonia: 2005 and 2009. Water Resources Management, 26: 1665-1676.

SUNKAR, R; KAPOOR, A and ZHU, J K (2006). Posttranscriptional induction of two $\mathrm{Cu} / \mathrm{Zn}$ superoxide dismutase genes in Arabidopsis is mediated by downregulation of miR398 and important for oxidative stress tolerance. Plant Cell, 18: 2051-2065.

TUNC-OZDEMIR, M; MILLER, G; SONG, L; KIM, J; SODEK, A; KOUSSEVITZKY, S and SHINTANI, D (2009). Thiamin confers enhanced tolerance to oxidative stress in Arabidopsis. Plant Physiology, 151: 421-432.

YOSHIBA, Y; KIYOSUE, T; NAKASHIMA, K; YAMAGUCHI-SHINOZAKI, K and SHINOZAKI, K (1997). Regulation of levels of proline as an osmolyte in plants under water stress. Plant Cell Physiol, 38: 1095-1102.

ZHANG, W; HAN, D Y; DICK, W A; DAVIS, K R and HOITINK, H A J (1998). Compost and compost water extract-induced systemic acquired resistance in cucumber and Arabidopsis. Phytopathology, 88: 450455. 